\title{
SABINE'S GULLS IN SOUTHEASTERN MANITOBA, FALL 1977
}

\section{PETER TAYLOR, P.O. Box 597, Pinawa, Manitoba R0E 1L0}

During fall 1977, three separate records of the Sabine's Gull, probably involving four individuals, were made in southeastern Manitoba. Since there are only two previous records of this species in southern Manitoba, the 1977 sightings are described in detail. ${ }^{2}$

On September 4, 1977, at about 3:30 p.m., I observed an adult Sabine's Gull in breeding plumage, feeding with about 100 Bonaparte's Gulls at the Lac du Bonnet sewage lagoons. Rudolf Koes and Richard Knapton joined me about 6 p.m., and all three of us observed the bird for about 20 minutes as it swam about, picking insects from the surface of the water. It was photographed down to about 25 metres. It was rather tamer than the Bonaparte's Gulls and appeared relatively undisturbed by our presence. It was not seen again on several subsequent visits, however, although the numbers of Bonaparte's Gulls remained fairly stable for about two weeks.

At about 9 a.m. on September 25, 1977, Richard Knapton and Rudolf Koes observed two immature Sabine's Gulls with about 30 Ring-billed Gulls on a patch of water in a muddy field beside Highway 8 about $5 \mathrm{~km}$ north of the Winnipeg Perimeter Highway. When Knapton attempted to photograph the birds, all of the gulls took flight. The Ring-bills landed again nearby, but the two Sabine's Gulls made two passes over the standing water, then gained altitude and disappeared southward. The day was wet, with low cloud, and it is possible that these two birds had been grounded by poor weather conditions and, on being disturbed, continued migrating.

The third record involved an adult bird in breeding plumage. It was seen by David Hatch on four occasions and once by Doug Kyle between October 17 and 25, 1977, on a pond near Stony Mountain Penitentiary, about $24 \mathrm{~km}$ north of Winnipeg.

All the sightings described were made by experienced observers at distances down to 25 metres, using optical equipment up to $25 x$ magnification, and all pertinent field marks were noted.

According to Godfrey, the breeding range of Sabine's Gull includes coasts and islands of much of the Canadian arctic, and migration to the South American winter range occurs mainly along the Pacific coast. ${ }^{3}$ He describes it as a rare migrant in the Canadian interior, with records in every province from British Columbia to New Brunswick. The status of the species in Manitoba and Saskatchewan was reviewed by Copland in 1969.' Although small numbers are seen regularly in June at Churchill ${ }^{4}$, and it has been suggested that some birds may reach Hudson Bay after an overland flight, there are only two previous records for southern Manitoba. On October 4, 1945, a bird in winter plumage was observed by Soper at Lake Audy in Riding Mountain National Park. ${ }^{7}$ A Sabine's Gull was present on the Water Diversion Channel at Portage la Prairie from October 19 to 24, 1970². It was reported by Harold McPherson, then stationed at the Portage la Prairie RCAF base, and its identity was confirmed by Jim Carson and Herb Copland of the Manitoba Museum of 
